\title{
Assessment of Factors Causing Coffee Yield Gap Among Smallholder Farmers in Mbinga and Mbozi Districts
}

Leonard Kauwedi Kiwelu ( $\sim$ leonardkiwelu@gmail.com )

Tanzania Coffee Research Institute https://orcid.org/0000-0002-4250-4341

Philip Damas

Sokoine University of Agriculture Faculty of Agriculture

Zena Mpenda

Sokoine University of Agriculture Faculty of Agriculture

\section{Research}

Keywords: Smallholder coffee farmers, coffee varieties, yield gap

Posted Date: February 25th, 2021

DOl: https://doi.org/10.21203/rs.3.rs-181896/v1

License: (c) (i) This work is licensed under a Creative Commons Attribution 4.0 International License.

Read Full License 


\title{
ASSESSMENT OF FACTORS CAUSING COFFEE YIELD GAP AMONG SMALLHOLDER FARMERS IN MBINGA AND MBOZI DISTRICTS
}

\author{
Leonard Kiwelu ${ }^{1}$, Philip Damas ${ }^{2}$ and Zena Mpenda ${ }^{3}$
}

\author{
${ }^{1}$ School of Agricultural Economics and Business Studies (SAEBS), Department of \\ Agricultural Economics and Agribusiness, Sokoine University of Agriculture (SUA), \\ Morogoro, Tanzania \\ ${ }^{2}$ School of Agricultural Economics and Business Studies (SAEBS), Department of Food \\ and Resource Economics, Sokoine University of Agriculture (SUA), Morogoro, Tanzania
}

\begin{abstract}
This study assesses the factors causing coffee yield gap among smallholder in the study area. The aim of this study is to increase coffee productivity from the current level. The primary data were collected from 218 adopters and 102 non-adopters of improved coffee varieties using a structured questionnaire. The descriptive statistics was used to assess yield gap and linear regression model was used to determine factors causing yield gap among smallholder farmers in the study area. The findings showed that the yield potential (3000 kg/ha and $1000 \mathrm{~kg} / \mathrm{ha}$ ) for improved and traditional coffee varieties respectively has not yet been realized by farmers and there is a large gap between the average coffee yield (1141 kg/ha and $384 \mathrm{~kg} / \mathrm{ha}$ ) gained by smallholder farmers growing improved coffee varieties and farmer growing traditional coffee varieties respectively. The yield gap from smallholder farmers with improved coffee varieties was $2000 \mathrm{~kg} / \mathrm{ha}$ and $646 \mathrm{~kg} / \mathrm{ha}$ from traditional coffee varieties. The main factors causing coffee yield gap were lack of access to extension services ( $p<0.000)$, plant population (0.007), low use of fertilizer $(p<0.002)$, coffee diseases ( $p$ <0.008). To minimize coffee yield gap in Tanzania promotion of the use of improved coffee varieties, fertilizer and agro-inputs is important.
\end{abstract}

Key words: Smallholder coffee farmers, coffee varieties, yield gap

\footnotetext{
${ }^{1}$ PhD Student- School of Agricultural Economics and Business Studies (SAEBS), Department of Agricultural Economics and Agribusiness, Sokoine University of Agriculture (SUA), Morogoro, Tanzania.

${ }^{2}$ School of Agricultural Economics and Business Studies (SAEBS), Department of Food and Resource Economics, Sokoine University of Agriculture (SUA), Morogoro, Tanzania.

${ }^{3}$ School of Agricultural Economics and Business Studies (SAEBS), Department of Food and Resource Economics, Sokoine University of Agriculture (SUA), Morogoro, Tanzania.
} 


\subsection{Introduction}

Coffee is among of the important tropical valuable and traded commodities produced in 70 countries in the world (Sänger, 2018). The average total coffee production by all exporting countries between 2008 and 2018 was 146997 thousand 60kg bags of which Brazil contributed about $35 \%$ of all coffee produced, Vietnam 17\%, Colombia $6 \%$, Indonesia 7\%, Ethiopia 4\%, Uganda 3\%, Côte d'Ivoire 2\%, Kenya 0.9\% and Tanzania $0.7 \%$ (ICO, 2018a). The productivity of coffee in Tanzania is ranging from 250 to 300 $\mathrm{kg} / \mathrm{ha}$ for Arabica coffee produced by smallholder farmers (BOT, 2017). The productivity levels of other coffee growing countries such as Kenya $302 \mathrm{~kg} / \mathrm{ha}$ (ICO, 2019a), Ethiopia $802 \mathrm{~kg} / \mathrm{ha}$ (Bickford, 2019), Rwanda $880 \mathrm{~kg} / \mathrm{ha}$ (Nzeyimana, 2018) and Uganda 2100 $\mathrm{kg} / \mathrm{ha}$ (ICO, 2019b) are relative higher than Tanzania. In general, it can be argued that coffee yield from smallholder farmers in Tanzania is low despite of Tanzania having coffee varieties with potential of producing $3000 \mathrm{~kg} / \mathrm{ha}$ and $1000 \mathrm{~kg} / \mathrm{ha}$ for improved and traditional coffee varieties respectively the coffee yield from smallholder farmers is lower compared to the potential yield levels (Kilambo et al., 2015). Progressive promotion of high yielding coffee varieties and replacement of old coffee trees with improved coffee varieties coupled with farmer training on the implementation of good agricultural practices (GAPs) were expected to increase coffee yield and close the yield gap. Yield gap analyses method was used by this study to understand the factors causing coffee yield gap among smallholder farmers in the study area. The findings from this study will help to inform policy makers, researchers and coffee producers on the strategies to be used to minimize yield gap among smallholder farmers in the study area.

\subsection{Theoretical, Empirical and Conceptual Frameworks}

\subsubsection{Theoretical framework}

Agricultural production economics is concerned primarily with economic theory as it relates to the producer of agricultural commodities (Debertin, 1986). The major concerns in agricultural production economics among other goals and objectives of the farm manager, choice of outputs to be produced, allocation of resources among outputs. The theory of utility maximization has been used extensively to explain the preference of inputs by farmers (Muellbauer, 1974). This theory predicts that farm productivity, measured by marginal factor products, will differ over farms using different levels of inputs. This theory considers a simplified view of the economy in which production output is determined by the amount of labour involved and the amount of capital invested. The strategies of increasing the coffee production in Tanzania include encouraging investment 
on man power through training, dissemination of improved seedlings, remove of taxes on agricultural related inputs such as fertilizer, pesticides and herbicides (TCB, 2012a). Therefore, the Cobb Douglas production function is useful as the basic framework for understanding the causes of gap resulted from utilizing the major factors coffee production in the study area.

\subsubsection{The empirical framework}

Different approaches such as field experiment (van Ittersum et al., 2013), crop growth simulation models (Lu \& Fan, 2013; and van Bussel et al., 2015), socio-economic survey (Tamene et al., 2016), and precision agriculture (Schulthess et al., 2013; Tittonell \& Giller, 2013) have been used to assess farmers' yields and yield gaps between households. Field experiments approach is used to compare farmers yield 'control' and research yield within the experimental plots (van Ittersum et al., 2013). This approach does not set the optimum yields to the level attainable by farmers and the limited number of test locations makes it difficult to upscale to larger areas (Tittonell \& Giller, 2013). Crop growth simulation models (Lu \& Fan, 2013; and van Bussel et al., 2015), compare the potential yield with actual yield but requires intensive data for model input, calibration and validation (van Ittersum et al., 2013). Precision agriculture which is fast and accurate is used to measure yield of plots in real time but it is more of technology intensive (Tittonell \& Giller, 2013). Socio-economic survey capture yield harvested by smallholder farmers and corresponding agronomic/management practices depends much on farmers memory and it is time saving (Tamene et al., 2016). This study therefore opts to use the socio-economic survey because of the nature of data collected from the study area depended on farmers records.

\subsubsection{The conceptual framework}

The conceptual framework developed in this study was mainly intended to determine a set of one or more factors of coffee production that will bring about optimal levels of coffee output for smallholder farmers in Mbinga and Mbozi districts. To estimate the yield gap among smallholder farmers, the analysis of input preference and usage is grounded in the theory of utility maximization (Huffman, 2011 and Muellbauer, 1974). Following that theory, it is hypothesized that farmers would prefer the use of an input as long as the utility derived from the application is greater than that of other inputs. An important conceptualization of this study is that preference of an input usage is not an end in itself. That is the utility of the farmer is not only maximized by application of an input, but also by the achievement of set objectives or outcomes. Farmers use inputs in order to achieve some objectives, some are subjective and others are objective. Some objectives for using 
some inputs include improved quality of coffee berries, increased productivity and profitability of coffee. This study therefore provides an opportunity to examine which factors play a significant role in both coffee productivity (fig. 1).

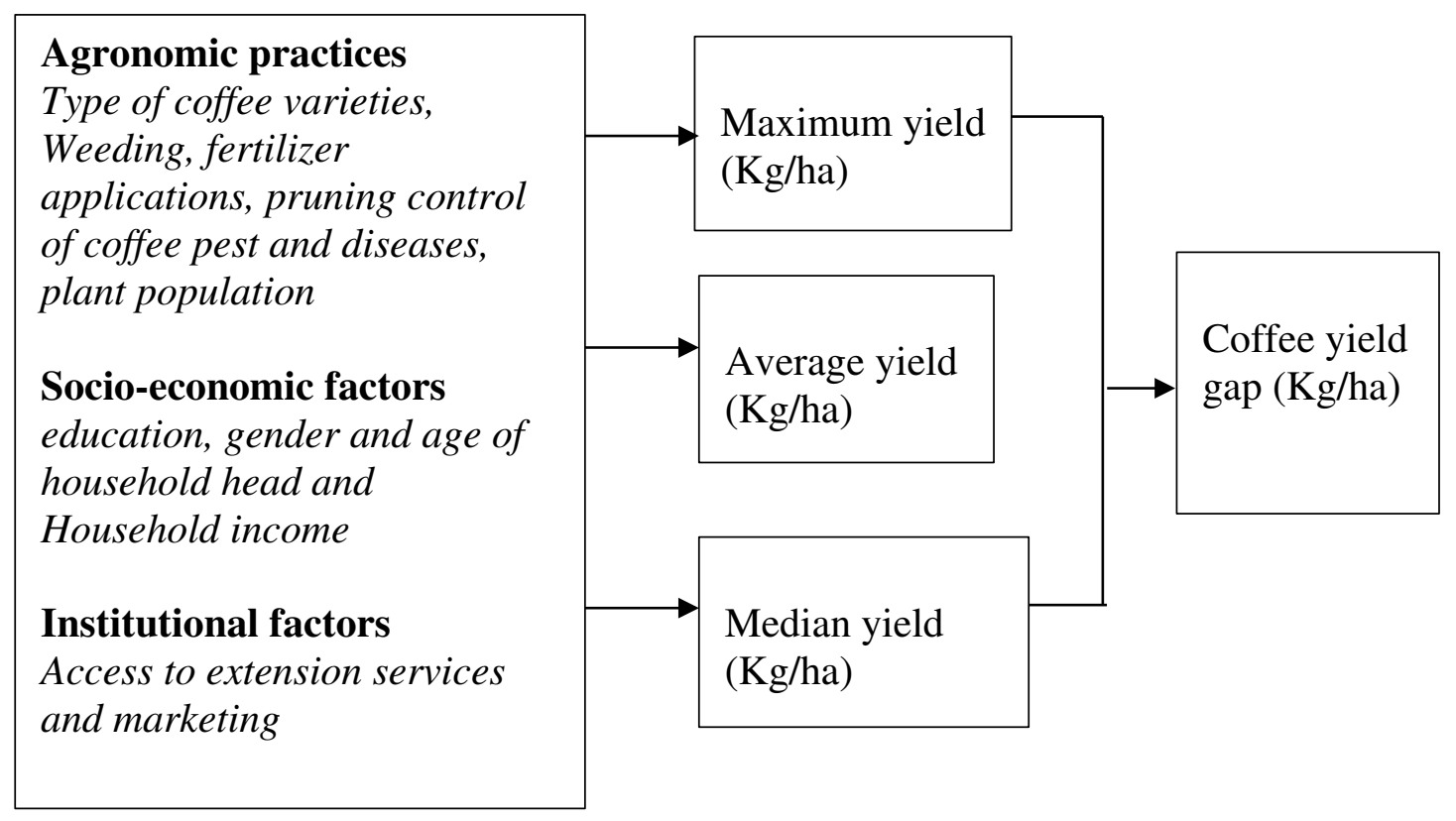

Figure 1: Conceptual framework developed by author

\subsection{Methodology}

\subsubsection{Description of the study area}

This study was conducted in two coffee producing Districts in Tanzania, namely Mbozi in Songwe Region (Figure 2. a) and Mbinga in Ruvuma Region (Figure 2. b). The two districts were picked to represent the other coffee producing districts because they are leading in Arabica coffee production, and the dissemination of improved coffee varieties to smallholder farmers has been going on since 2005 to date. Mbozi District lies between $8^{\circ} 45^{\prime} 0^{\prime \prime} \mathrm{S}$ and $32^{\circ} 45^{\prime} 0^{\prime \prime}$ E. It is bordered to the North by Chunya District, to the East by Mbeya Urban and Ileje Districts, to the South by Zambia and to the West by Rukwa Region. The population of Mbozi District in 2012 was estimated to be 446339 (URT, 2013). The altitude of Mbozi district lies between 900 and 2750 meters above the sea level. The District receives average rainfall between $1350 \mathrm{~mm}$ and $1550 \mathrm{~mm}$ per annum; while temperatures range between $20^{\circ} \mathrm{C}$ to $28^{\circ} \mathrm{C}$. The major food crops grown in the area include maize, paddy, sorghum, finger millet, bulrush millet, sweet potatoes, Irish potatoes, groundnuts and beans while the cash crops grown are coffee, simsim and sunflower. Nearly $80 \%$ of the households own at least one type of livestock. The common types of livestock owned include cattle, goats, sheep, pigs, poultry, donkeys and turkeys. Farmers' income from livestock and products thereof accounts for $23 \%$ of household income

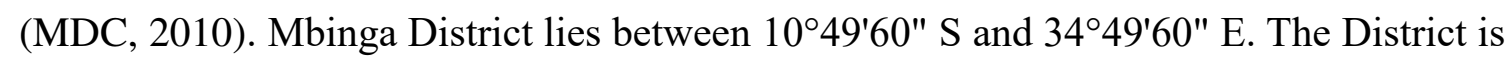


bordered to the North by Njombe Region, to the East by Songea Rural and Songea Urban Districts, to the South by Mozambique and to the West by Lake Nyasa. The population of Mbinga District in 2012 was estimated to be 224386 (URT, 2013). The altitude of this District lies between 900 and 1350 meters above sea level; with some points in the highland reaching over 2000 meters above sea level. The District receives average rainfall between 1200 and $1500 \mathrm{~mm}$ per annum; while temperatures range between $13^{\circ} \mathrm{C}$ in the highland to $30^{\circ} \mathrm{C}$ on the lake shore. The major crops in the District include maize, sorghum, cashew, coconut, bananas, beans, cassava, finger millet and cash crops like coffee, tobacco and Avocado (a new emerging cash crop). Likewise, smallholder farmers deal with livestock keeping, bee keeping, fish farming and lumbering of hard wood. The common types of livestock owned include cattle, goats, sheep, pigs, and poultry. The dominant farming systems in the District is characterised by Matengo pits in mountainous areas while conventional ridges and mounds are common in rolling hills and lake shore zones, respectively.

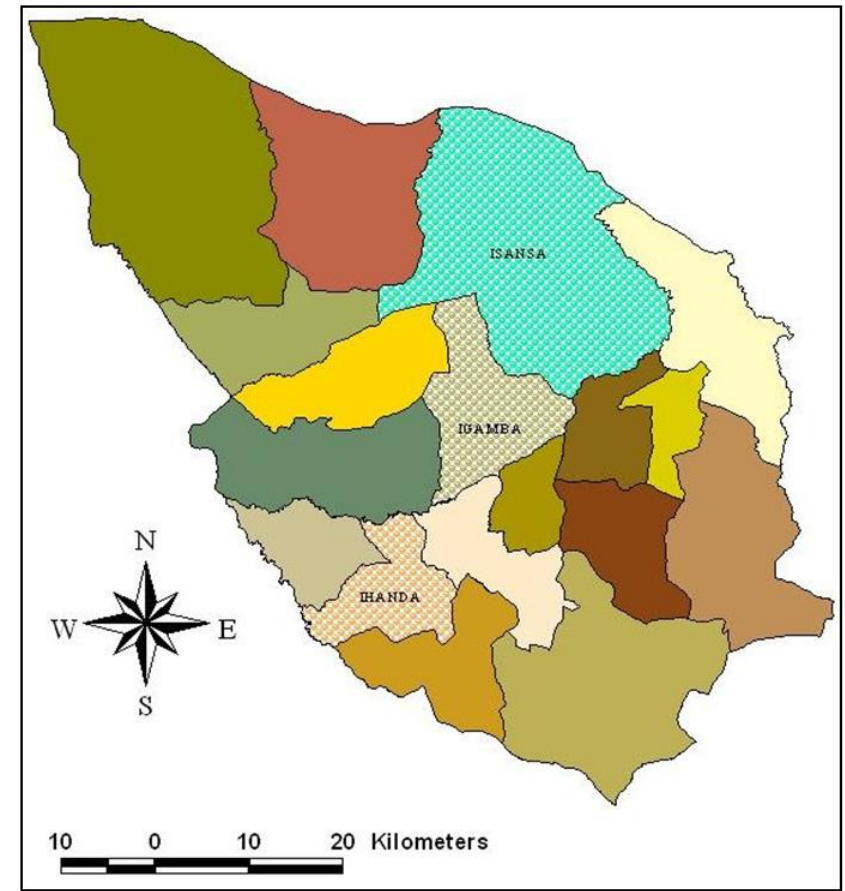

a

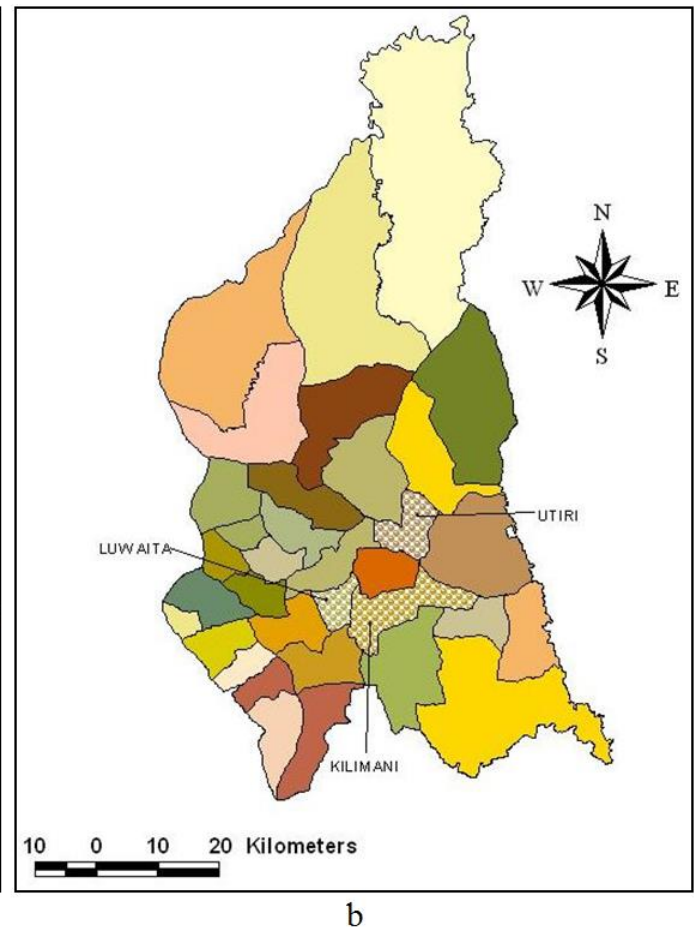

b

Figure 1.1: a. Map of Mbozi District, study wards in dotted texture; b. Map of Mbinga district, study wards in dotted texture

\subsubsection{Research design}

The present study employed a cross-sectional research design. The cross-sectional design was used because it is suitable for description purposes as well as for the determination of relationship between variables and it is cost effective and saves time over longitudinal and 
panel data. This design has been recommended by several scholars including (Levin, 2006; Omair, 2015; Setia, 2016).

\subsubsection{Sampling techniques}

\subsubsection{Sampling frame}

Sampling frame included households engaged in coffee production in four villages. Coffee growers were selected from family household's viewpoint as a unit of assessment. Also, similar check-list of questions was used in Focus Group Discussions (FGD) and interview with Key Informants' (KIIs) so as to validate information obtained from households and FGD respectively.

\subsubsection{Sampling procedure}

To collect the representative sample, purposive and random sampling procedure were used in selecting districts, wards, villages and the household. At the first stage, purposive sampling has been applied in selecting the two districts intended by this study. Secondly, random sampling was applied in selecting wards from the long list of wards where coffee is grown. The third stage involved random sampling of villages with adopter of improved coffee varieties and lastly, random sampling was applied in selecting coffee households growing improved and traditional coffee varieties in the villages with at least 100 number of coffee trees which is the minimum number of improved coffee trees farmer a farmer can own to break even. All these stages involved collaboration with districts and wards extension officers. Finally, from the list of coffee growers developed in the second and third stage, a required sample size of respondents was proportionally selected from each village.

\subsubsection{Sample size determination}

This study used the formula in equation 1 , to determine sample size of smallholder farmers growing improved and traditional coffee varieties from Mbozi and Mbinga districts (Krejcie, 1970a). Therefore, a sample size of 320 was collected from six randomly selected wards: Igamba, Isansa and Ihanda in Mbozi district Kilimani, Utiri and Luwaita in Mbinga district as shown in (Table 1).

$S=\frac{X^{2} N P(1-P)}{d^{2}(N-1)+X^{2} P(1-P)}$

Where: $S=$ Required sample size, $X=z$ value (assumed to be 1.96 for $95 \%$ confidence level), $\mathrm{N}=$ Population size, $\mathrm{P}=$ Population proportion (assumed to be 0.5 since this would provide the maximum sample size), $\mathrm{d}=$ degree of accuracy (5\%), expressed as a 
proportion (0.05). Accordingly, Mbozi district consists 930 households and Mbinga district consist of 990 households, making a total of 1920 target households.

$n=\frac{1.96^{2} \times 1920 \times 0.5 \times 0.5}{0.05^{2} \times(1920-1)+\left(1.96^{2} \times 0.5 \times 0.5\right)}=320$

Table 1: Sample Districts and Number of Sample Households

\begin{tabular}{lccccc}
\hline & $\begin{array}{c}\text { Approx. sub- } \\
\text { pop. (20-30\% } \\
\text { are coffee } \\
\text { farmers) }\end{array}$ & $\begin{array}{c}\text { Sampling } \\
\text { fraction }\end{array}$ & $\begin{array}{c}\text { Sub- } \\
\text { sample }\end{array}$ & $\begin{array}{c}\text { Improved } \\
\text { varieties }\end{array}$ & $\begin{array}{c}\text { Traditional } \\
\text { varieties }\end{array}$ \\
District & 930 & 0.48 & 155 & 97 & 58 \\
Mbozi & 990 & 0.52 & 165 & 121 & 44 \\
Mbinga & $\mathbf{1 9 2 0}$ & & $\mathbf{3 2 0}$ & $\mathbf{2 1 8}$ & $\mathbf{1 0 2}$ \\
Total & & & & & \\
\hline
\end{tabular}

\subsubsection{Data Collection}

\subsubsection{Secondary and primary data collection}

The study used both secondary and primary data. Primary data were collected using household questionnaire to interview household heads while secondary data were collected from different literature related to coffee sector. Primary data were collected using household survey conducted to 320 household heads owning traditional coffee varieties and improved coffee varieties. Structured questionnaire was designed in a set of open and close ended questions in respect to specific objectives. The information collected includes: household demographic characteristics such as sex, age, family size, number of years in formal education of the household head, household labour capacity, access to extension services, and group membership. Other information was land size, farm management practices such as, application of fertilizers, weeding, plant population and income sources.

\subsubsection{Focus group discussion (FGDs)}

Focus Group Discussions (FGDs) were used to collect primary data. About 42 participants were involved in making two groups from each district; one for those with improved varieties and the other for those with traditional varieties making a total of four groups. Each group had that comprised $7-8$ participants (including 1 to 2 females) who were purposively selected among coffee producers. Participants in FGDs were different from those involved in questionnaire interviews. The rationale for the choice of focus group discussion method was that it helped to capture in-depth information on factors affecting coffee yield among adopters and non-adopters of improved coffee varieties and to validate 
some information gathered during primary data collection from the households in the study area.

\subsubsection{Key informant interviews (KIIs)}

Key Informants' Interview (KIIs) was used to collect primary data. Key informants included ward extension staff, local leaders one from each ward in the study area respectively, District Coffee Subject Matter Specialist (DCSMS) and TaCRI extension officer to make a total of 9 KIIs in the discussions from each district in order to obtain their opinion on factors affecting coffee yield among adopters and non-adopters of improved coffee varieties and to validate some information gathered during primary data collection from the households and focus group discussions.

\subsubsection{Data analysis}

\subsubsection{Coffee yield estimation among smallholder farmers}

Data collected through farmer interviews were coded and analysed using the SPSS whereby descriptive statistics (i.e. frequencies, percentages, means, minimum and maximum values of variables) were determined. The coffee yield reported by farmers recall were converted to standard unit conversion factors of which for this study was $\mathrm{kg} / \mathrm{ha}$ and findings were compared using t-test of difference in means to establish if there is any statistically significant difference between yield obtained by smallholder farmers with improved coffee varieties and those with traditional coffee varieties.

\subsubsection{Yield gap estimation among smallholder farmers adopter and non-adopters}

Yield gap ( $\mathrm{Yg})$ is a quantitative difference between average research yield (generally reported from research trials) and average farmers yield (generally: obtained from acceptable farmer management practices) over some specified spatial and temporal scale holding other crop attributes remain constant (Sadras, 2015). Yield gap as the difference between the maximum farmer yields (attainable yield) and the average farmer yields (Lobell et al., 2009; Tamene et al., 2016). Yield gaps were analyzed by comparing farmers yield with yield data from research studies carried out by TaCRI. The research yields data was collected from the recently published reports from TaCRI. The average farmer yield can be affected by outliers, then for purpose of this study the median yield was used as a reference attainable yield versus potential on-farm experimental yield. Therefore, coffee yield gap $\mathrm{Yg}(\mathrm{kg} / \mathrm{ha})$ is defined as the difference between the potential on-farm 
experimental yield (Yr) and the attainable yield obtained from farmers management practices (Yf).

$Y_{g}=Y_{r}-Y_{f}$

Where: $Y_{g}=$ Yield gap, $Y_{r}=$ research yield and $Y_{f}=$ the average farmers' yield.

The t-test analysis for the two categories of respondents with improved coffee varieties and respondents with traditional coffee varieties were done to compared difference in means to establish if there is any statistically significant difference between yield gap among smallholder farmers with improved coffee varieties and those with traditional coffee varieties.

The average of these yield gaps was also calculated as the expression of overall yield gap index as follows:

$\left[I_{(y g)}=\frac{P_{(f y)}-A_{(f y)}}{P_{(f y)}} x 100\right]$

Where: $I_{(y g)}=$ Index of yield gap, $P_{(f y)}=$ Potential farm yield (average) obtained by the researchers of the areas $A_{(f y)}=$ Actual farm yield (average) obtained by the different categories of farmers.

\subsubsection{Estimation of factors affecting coffee yield}

Linear regression analysis and correlation methods were used to estimate predictors of yield gap among smallholder farmers in the study area. These methods have been widely used in yield gap studies to show specific factors influencing crop yields However, the heterogeneity in smallholder farms is likely to result in high spatial variability in yield gaps and their causes. To obtain a spatial view of the causes of yield gaps on smallholder farms, multivariate regression analysis was done. Some important variables were taken on the bases of perceptions. The production function regression model (Yusi, 2016) as cited in (Echevarria, 1998) was chosen and hypothesis of the study were taken into consideration. The following regression equation was estimated,

$Y=\beta_{0}+\beta_{1} X_{1}+\beta_{2} X_{2}+\beta_{3} X_{3}+\beta_{4} X_{4}+\cdots+\beta_{9} X_{9}+e$

Where $Y=$ coffee yield gap of $i^{\text {th }}$ crop $(\mathrm{kg} / \mathrm{ha}), \mathrm{X}_{1}=$ gender (female, male), $\mathrm{X}_{2}=$ age of the farmers (years), $X_{3}=$ household size, $X_{4}=$ level of education (years spent in school), $\mathrm{X}_{5}=$ household size (total number in the household), $\mathrm{X}_{6}=$ Extension contacts, $\mathrm{X}_{7}=$ farm size (ha), $\mathrm{X}_{8}=$ Agronomic practices (weeding, fertilizer application, pruning and control 
of coffee pests and diseases), $\mathrm{X}_{9}=$ Technology adoption index and e $=$ error term, $\beta_{0}=$ Intercept, $\beta_{1} \ldots \beta=$ Regression Coefficient.

\subsection{Findings and Discussion}

\subsubsection{Land under coffee production and type of coffee varieties grow}

The findings from the study area showed that, the average land size under improved coffee varieties is 1.6 ha and 2.19 ha is under traditional coffee varieties. The findings imply that, the area under improved coffee varieties is small than area under traditional coffee varieties. The findings in Table 2 indicate that, $14 \%$ of respondents in the study area planted only improved coffee varieties obtained from TaCRI, 54\% of respondents have planted both improved and traditional coffee varieties whereas $32 \%$ of respondents have only traditional. The finding implies that the number of farmer with improved coffee varieties has increased by 13 times of what was reported in 2017 (Mhando, 2017 and TaCRI, 2017).

Table 2: Coffee varieties planted by smallholder farmers

\begin{tabular}{lcccccc}
\hline Coffee varieties planted & \multicolumn{2}{c}{ Mbinga } & \multicolumn{2}{c}{ Mbozi } & \multicolumn{2}{c}{ Total } \\
\cline { 2 - 7 } & Frequency & $\mathbf{\%}$ & Frequency & \% & Frequency & \% \\
\hline Improved varieties & 30 & 9 & 16 & 5 & 46 & 14 \\
Improved and Traditional & 91 & 28 & 81 & 25 & 172 & 54 \\
Traditional & 44 & 14 & 58 & 18 & 102 & 32 \\
Total & $\mathbf{1 6 5}$ & $\mathbf{5 2}$ & $\mathbf{1 5 5}$ & $\mathbf{4 8}$ & $\mathbf{3 2 0}$ & $\mathbf{1 0 0}$ \\
\hline
\end{tabular}

\subsubsection{Coffee yield estimation}

The findings in Table 3 show that, the average coffee yield from smallholder farmers with improved coffee varieties is $1141 \mathrm{~kg} / \mathrm{ha}$, median yield was $1000 \mathrm{~kg} / \mathrm{ha}$, maximum was $3842 \mathrm{~kg} / \mathrm{ha}$ and minimum was $327 \mathrm{~kg} / \mathrm{ha}$. Respondents with traditional coffee varieties gain an average yield of $384 \mathrm{~kg} / \mathrm{ha}$, median yield was $354 \mathrm{~kg} / \mathrm{ha}$, maximum yield was 850 $\mathrm{kg} / \mathrm{ha}$ and minimum yield was $126 \mathrm{~kg} / \mathrm{ha}$. The findings imply that, farmers with improved varieties have relative higher yield than farmers with traditional varieties. Similarly, the maximum yield recorded from smallholder farmers is an indication of possibilities to rise current coffee production from the current average yield to relative maximum yield. In addition, the finding implies that, at the farm level yield can be realized through proper input use and farm management. This findings support (Diro \& Erko, 2019; Wu, 2005) who reported that, farmers who adopted improved varieties gain higher yield than those with traditional varieties. The study conducted by (Maro et al., 2014; TCB, 2012a) recoded the average yield of $555 \mathrm{~kg} / \mathrm{ha}$, maximum yield of $1554 \mathrm{~kg} / \mathrm{ha}$ and minimum yield 51 
$\mathrm{kg} / \mathrm{ha}$ in Mbinga district and average yield of $422 \mathrm{~kg} / \mathrm{ha}$, maximum yield of $1745 \mathrm{~kg} / \mathrm{ha}$ and minimum yield $253 \mathrm{~kg} / \mathrm{ha}$ in Mbozi district.

Table 2:Coffee yield attained by smallholder farmers $(\mathrm{kg} / \mathrm{ha})$

\begin{tabular}{lccc}
\hline Descriptions & $\begin{array}{c}\text { Improved } \\
(\mathrm{n}=112)\end{array}$ & $\begin{array}{c}\text { Traditional } \\
(\mathrm{n}=101)\end{array}$ & $\begin{array}{c}\text { Total } \\
(\mathrm{n}=213)\end{array}$ \\
\hline Average farm yield (kg/ha) & 1141 & 384 & 782 \\
Median farm yield (kg/ha) & 1000 & 354 & 623 \\
Maximum farm yield (kg/ha) & 3842 & 850 & 3842 \\
Minimum farm yield (kg/ha) & 327 & 126 & 126 \\
Std. Deviation & 613 & 186 & 597 \\
F-test & 141.813 & & \\
Sign. & 0.000 & & \\
\hline
\end{tabular}

\subsubsection{The estimation of coffee yield gap}

The yield gap was computed by subtracting the average research coffee yield reported from research trials and the median yield obtained from farmers in the study area. The findings in Table 4 indicates that, the median yield gap from smallholder farmers with improved coffee varieties was $2000 \mathrm{~kg} / \mathrm{ha}$ and $646 \mathrm{~kg} / \mathrm{ha}$ from traditional coffee varieties. The possible reason for yield gap include low use of fertilizer (Tamene et al., 2016). Likewise, yield among smallholder farmers may also varies due to biological, socioeconomic, climate and institutional/policy (Mondal, 2011 and Mwakalobo, 2005).

Table 3: The yield gap analysis (kg/ha) in the study area

\begin{tabular}{lcc}
\hline Description & Improved & Traditional \\
\hline Research yield (kg/ha) & 3000 & 1000 \\
Average farmer yield & 1141 & 384 \\
Average yield gap & 1859 & 616 \\
Median yield & 1000 & 354 \\
Median yield gap & $\mathbf{2 0 0 0}$ & $\mathbf{6 4 6}$ \\
Std. Deviation of the yield gap & 1859 & 616 \\
\hline
\end{tabular}

\begin{tabular}{lll}
\hline F-Value $\quad 383.493$ & Sign. & 0.000
\end{tabular}

\subsubsection{The factors causing coffee yield gap among smallholder farmers}

To identify the determinants of coffee yield gap among adopters and non-adopters of improved coffee varieties, linear regression analysis was done. The findings indicated that the variables specified in the model fitted well because the $F(14,198)$ and statistically significant at $\mathrm{P}=$ value 0.000 with adjusted $\mathrm{R}$-squire 0.93 which show the strength of the model. 
The findings in Table 5 show that, visits by extension officers have positive coefficient (129.645) and statistically significant at 0.000 implying that, lack of extension services to farmers contribute to increase coffee yield gap. Different scholars (Ghimire et al., 2015; Lugandu, 2013; Teferi et al., 2015) documented that, farmer access to extension services help in improving farm management practices hence increase the chance of reducing yield gap. Therefore, the transfer of the recommended agricultural practices through extension officers could effectively help farmers minimize yield gaps.

The findings also indicated that plant population per ha have positive coefficient and statistically significant at (0.007). The finding implies that plant population with inadequate number of productive primary branches could lead to increase yield gap. According to TaCRI (2020), the average number of productive primary branches per tree are 30 to 38 trees.

The findings also indicated that, infestation of coffee diseases due to poor control of CBD and CLR have positive coefficient (4.684) and statistically significant at $\mathrm{P}<=0.000$. Fungicides are used to control major coffee diseases which include CBD and CLR but the price of fungicides were reported to be high and farmer fail to purchase and apply the right dosage at the recommended rate and time. According to (Kilambo et al., 2015) without control of these diseases crop yield will be reduced by 50 to $0 \%$ which is the big crop loss. Pest and diseases of coffee reduce yields and sometimes killing trees (Magina, 2011). Fungicide application is required to control major coffee diseases and contribute to increase coffee yield hence reduce the yield gap (TaCRI, 2011).

The findings also indicated that, the coefficient of the amount of fertilizer applied have was positive (0.073) and statistically significant at 0.008 level increase coffee yield gap. The findings imply that, smallholder farmers do not apply sufficient amount of fertilizer or either they don't apply at all hence cause the increased in yield gap. According to (Maro, 2014 and TaCRI, 2011), application of recommended fertilizer would contribute to increase coffee yield hence reduce the yield gap. The reason for low fertilizer application among smallholder farmers is due to high price of fertilizer. The possible alternative that farmer can afford and adopt is integrated soil fertility management (ISFM) proposed by (Maro, 2014 and TaCRI, 2011). Meanwhile the government should take the issue of input availability to farmers for reasonable price a s important agenda and put strategies to ensure that resource poor smallholder farmers who are productive get adequate amounts 
of quality inputs at the right time and reasonable price to obtain high yields. Technology adoption index (20.695), improved varieties (1210.367) and traditional varieties (1267.929) were positive and statistically significant at $1 \%$ causing increase in coffee yield gap.

Table 4: Liner regression model on factors causing coffee yield

\begin{tabular}{lccc}
\hline Descriptions & Coef. & $\mathrm{t}$ & $\mathrm{P}>\mathrm{t}$ \\
\hline Age of respondent & 0.462 & 0.45 & 0.650 \\
Sex of respondent & -43.208 & -1.26 & 0.210 \\
Marital status of respondent & -96.142 & -2.4 & 0.018 \\
Level of education of respondent & -0.427 & -0.01 & 0.989 \\
House hold size & 1.037 & 0.16 & 0.873 \\
Visits by extension officers & 129.645 & 3.92 & 0.000 \\
Plant population per ha & 0.018 & 2.7 & 0.007 \\
Coffee pests & 6.962 & 1.06 & 0.293 \\
Coffee diseases & 4.684 & 3.22 & 0.002 \\
Low use of fertilizer & 0.073 & 2.93 & 0.008 \\
Labour costs per ha & 0.000 & -4.12 & 0.000 \\
Technology adoption index & 20.695 & 26.78 & 0.000 \\
Dummy Improved & 1210.367 & 33.47 & 0.000 \\
Dummy traditional & 1267.929 & 40.17 & 0.000 \\
cons & -645.495 & -5.76 & 0.000 \\
\hline
\end{tabular}

\subsection{Conclusion and Recommendations}

\subsubsection{Conclusion}

The aim of this study is to understand factors causing yield gap among smallholder farmers in Mbinga and Mbozi districts. The study show, smallholder farmers with improved coffee varieties gain relative high coffee yield than farmers with traditional coffee varieties. The findings also show that, the yield gap among smallholder farmers is caused by number of factors including, lack of visits by extension officers to farmers, lack or insufficient application of fertilizer, poor or lack of control of coffee pests and diseases, type of coffee varieties planted by farmers and the extent of technology adoption by smallholder farmers in the study area.

\subsubsection{Recommendations}

In order to minimize coffee yield gap among smallholder famers and increase coffee production in Tanzania there is a need to strengthen extension services to help in dissemination of appropriate knowledge and skill to farmers to achieve high yield. Subsidized coffee input such as fertilizer, pesticides and fungicide required to smallholder farmer so as they can afford to apply the recommended rates of fertilizer, fungicides and 
pesticide to attain high yield further more progressive adoption of improved varieties and implementation of good agricultural practices is recommended to farmers.

\section{Authors' contributions}

The first author handled the data analysis and discussion of results. Other authors supervised the writing of the manuscript, proofread to ensure quality of the research as well as contributed to the revision of the study for publication. All authors read and approved the final manuscript.

\section{Author details}

${ }^{1}$ School of Agricultural Economics and Business Studies (SAEBS), Department of Agricultural Economics and Agribusiness, Sokoine University of Agriculture (SUA), Morogoro, Tanzania

${ }^{2}$ School of Agricultural Economics and Business Studies (SAEBS), Department of Food and Resource Economics, Sokoine University of Agriculture (SUA), Morogoro, Tanzania

\section{Authors' information}

LKK is a staff member of the Special Project Units at Tanzania Coffee Research Institute (TaCRI), Tanzania. He has M.Sc. degree in Agricultural Economics and Agribusiness from Sokoine University of Agricultural, Tanzania and B.A in Rural Development from Sokoine University of Agricultural, Tanzania. Currently he is Ph.D student in Agricultural Economics at Sokoine University of Agricultural, Tanzania. DP is a Senior Lecturer; and Dean of School of Agricultural Economics and Agribusiness (SAEBS). Department of Food and Resource Economics (DeFRE). Prior to joining the Sokoine University of Agriculture, he worked as a Scientific Officer at the Tanzanian Commission for Science and Technology (COSTECH). He holds a Bachelor of Science in General Agriculture and a Master of Science in Agricultural Economics from the Sokoine University of Agriculture. He also holds a PhD in Agricultural Economics from Bonn University. Dr. ZM is a lecturer and head of Department of Agricultural Food and Resource and Economics at the School of Agricultural Economics and Business studies (SAEBS) at 
Sokoine University of Agriculture (SUA), Tanzania. She has majored in economics of food safety standards in agro-food exports for developing countries. She has worked and done consultancy and assists SMEs in product development and processing specifically on dairy products, cooking oil, fish and vegetables.

\section{Acknowledgements}

We would like to express our special thanks to the Tanzania Coffee Research Institute (TaCRI), for the financial support.

\section{Availability of data and materials}

The data that support the findings of this study can be obtained from the authors based on the request.

\section{Competing interests}

The authors declare that they have no competing interests.

\section{Funding}

Tanzania Coffee Research Institute (TaCRI).

\section{REFERENCES}

Alimi, T., \& Manyong, V. M. (2000). Partial budget analysis for On-farm research. International Institute of Tropical Agriculture (IITA).

Arega, A., Tekalign, A., Solomon, T., \& Tekile, B. (2018). Effect of Inter and Intra Row Spacing on Tuber Yield and Yield Components of Potato ( Solanum tuberosum L .) in Guji zone, Southern Ethiopia. J Adv Plant Sci, 1(1), 102.

Asfaw, A., \& Admassie, A. (2004). The role of education on the adoption of chemical fertilizer under different socio-economic environments in Ethiopia. Agricultural Economics, 30(3), 215-228.

Bernard, H. R. (2006). Research methods in anthropology: Qualitative and quantitative approaches (4th ed). AltaMira Press.

Bickford, R. (2019). Ethiopia Coffee Annual Coffee Annual Report (GAIN Report No. ET1904; Global Agricultural Information Network, pp. 1-6). USDA Foreign Agricultural Services. 
BOT. (2017). Bank of Tanzania, Annual Report. 0067-3757, 213-234.

https://doi.org/ISSN 0067-3757

BOT. (2018a). Annual Reports For the Year Ended 30 June 2018 (p. 240) [Annual Report 2017/2018]. Bank of Tanzania.

BOT. (2018b). Bank of Tanzania Annual Report 2017/18.

BOT. (2019). Annual Reports for the Year ended on 30 June 2019 (p. 264). Bank of Tanzania.

Bushara, M. O., Elami, K. M., \& Elnagarabi, E. E. (2018). Adoption and Impact Assessment of Improved Technologies of Potato Crop Production Systems in Khartoum State, Sudan (2009-2010). International Journal of Economics \& Management Sciences, 07(03). https://doi.org/10.4172/2162-6359.1000527

Cellini Riegg, S., \& Kee Edwin, J. (2015). Cost-Effectiveness and Cost-Benefit Analysis. In Handbook of Practical Program Evaluation, Fourth (pp. 636-672).

Debertin, D. L. (1986). Agricultural production economics. Macmillan ; Collier Macmillan.

Diro, S., \& Erko, B. (2019). Impact of Adoption of Improved Coffee Varieties on Farmers Coffee Yield and Income in Jimma Zone. Agr Res \& Tech: Open Access $J ., 21(4)$.

Doss, C. R., \& Morris, M. L. (2001). How does gender affect the adoption of agricultural innovations? The case of improved maize technology in Ghana. Agricultural Economics, 25, 27-29.

Echevarria, C. (1998). A Three-Factor Agricultural Production Function: The Case of Canada. INTERNATIONAL ECONOMIC JOURNAL, 12(3), 13.

Feder, G., \& Umali, L. D. (1993). The adoption of agricultural innovations: A review. $43(3-4), 215-239$.

Ghimire, R., Wen-chi, H., \& Shrestha, R. B. (2015). Factors Affecting Adoption of Improved Rice Varieties among Rural Farm Households in Central Nepal. Rice Science, 22(1), 35-43.

Gittinger, J. P. (1982). Economic analysis of agricultural projects. THE ECONOMIC DEVELOPMENT INSTITUTE OF THE WORLD BANK The Johns Hopkins University Press BALTIMORE AND LONDON.

Huffman, W. E. (2011). Household Production Theory and Models. In J. L. Lusk, J. Roosen, \& J. F. Shogren (Eds.), The Oxford Handbook of the Economics of Food Consumption and Policy (pp. 34-74). Oxford University Press. https://doi.org/10.1093/oxfordhb/9780199569441.013.0003 
ICO. (2018a). Gender Equality in the Coffee Sector: An insight report from the International Coffee Organization (ICC-122-11; pp. 1-45). International Coffee Organization.

ICO. (2018b). Total production by all exporting countries. International Coffee

Organisation. http://www.ico.org/new_historical.asp?section=Statistics

ICO. (2018c). Total production by all exporting countries, International Coffee Organization.

ICO. (2019a). Country Coffee Profile: Kenya. The International Coffee Council, 124(7), $1-29$.

ICO. (2019b). Country Coffee Profile: Uganda. The International Coffee Council, 124(8), 1-47.

ICO. (2019c). Country Coffee Profile: Uganda. International Coffee Council, 8, 47.

Imron, K. D., \& Satrya, A. R. A. (2019). Women and Coffee Farming: Collective Consciousness towards Social Entrepreneurship in Ulubelu, Lampung. Jurnal Ilmu Sosial Dan Ilmu Politik, 22(3), 216-229. https://doi.org/10.22146/jsp.35366

Kaliba, A. R., Mazvimavi, K., Gregory, T. L., Mgonja, F. M., \& Mgonja, M. (2018). Factors affecting adoption of improved sorghum varieties in Tanzania under information and capital constraints. Agricultural and Food Economics, 6(1), 18. https://doi.org/10.1186/s40100-018-0114-4

Khonje, M., Manda, J., Alene, A. D., \& Kassie, M. (2015). Analysis of Adoption and Impacts of Improved Maize Varieties in Eastern Zambia. World Development $66,695-706$.

Kilambo, D. L., Mtenga, D. J., Ng’homa, N., Ng’omuo, R., Teri, J., \& Mlwilo, B. (2015). A Decade of Contributing to a Profitable and Sustainable Coffee Industry in Tanzania: The Arabica and Robusta Improvement Programmes. American Journal of Research Communication, 3(1), 31-35.

Kilambo, D. L., Reuben, S. O. W. M., \& Mamiro, D. P. (2013). Responses of Compact Coffee Clones Against Coffee Berry and Coffee Leaf Rust Diseases in Tanzania. Journal of Plant Studies, 2(2), p81. https://doi.org/10.5539/jps.v2n2p81

Kilambo, D., Mtenga, D., Homa, N., Ngomuo, R., Teri, J., \& Lwilo, B. (2015). A Decade of Contributing to a Profitable and Sustainable Coffee Industry in Tanzania: The Arabica and Robusta Improvement Programmes. 4, 42-46.

Krejcie, R. V., \& Morgan, D. W. (1970a). Determining Sample Size for Research Activities. Educational and Psychological Measurement, 30(3), 607-610. https://doi.org/10.1177/001316447003000308 
Krejcie, R. V., \& Morgan, D. W. (1970b). Determining Sample Size for Research Activities. Educational and Psychological Measurement, 30(3), 607-610. https://doi.org/10.1177/001316447003000308

Lemchi, J., Tshiunza, M., \& Tenkouano, A. (2004). Factors driving the intensity and rate of cooking banana adoption in Nigeria. Journal of Agriculture and Social Research (JASR), 3(2), 135-166. https://doi.org/10.4314/jasr.v3i2.2801

Levin, K. A. (2006). Study design III: Cross-sectional studies. Evidence-Based Dentistry, 7(1), 24-25. https://doi.org/10.1038/sj.ebd.6400375

Lobell, D. B., Cassman, K. G., \& Field, C. B. (2009). Crop Yield Gaps: Their Importance, Magnitudes, and Causes. Annual Review of Environment and Resources, 34, 179-204. https://doi.org/10.1146/annurev.environ.041008.093740

Lu, C., \& Fan, L. (2013). Winter wheat yield potentials and yield gaps in the North China Plain. Field Crops Research, 143, 98-105. https://doi.org/10.1016/j.fcr.2012.09.015

Lugandu, S. (2013). Factors Influencing the Adoption of Conservation Agriculture by Smallholder Farmers in Karatu and Kongwa Districts of Tanzania. Research on Poverty Alleviation, Dar Es Salaam., 69.

Luzinda, H., Nelima, M., Wabomba, A., Musoli, P. C., \& Kakuru, A. (2018). Factors Influencing Adoption of Improved Robusta Coffee Technologies in Uganda. Uganda Journal of Agricultural Sciences, 18(1), 33-41. http://dx.doi.org/10.4314/ujas.v18i1.3

Lyon, S. (2019). Business Anthropology's Lens into Gender Equality: Assessing the Impact of "Smart Economics" in the Coffee Sector University of Kentucky. International Journal of Business Anthropology, 9(2), 18.

Magesa, J. M., Msogoya, T. J., \& Rweyemamu, C. L. (2018). Effect of seedling fibrous roots on field performance of hybrid coffee varieties. African Journal of Agricultural Research, 13(13), 627-634.

Magina, F. (2011). A Review of Coffee Pest Management in Tanzania (2nd Edition). Tanzania Coffee Research Institute.

Mariano, M. J., Villano, R., \& Fleming, E. (2012). Factors influencing farmers' adoption of modern rice technologies and good management practices in the Philippines. Agricultural Systems, 110, 41-53. https://doi.org/10.1016/j.agsy.2012.03.010

Maro, G. (2014). Economic Optimization of Nutrient Application to Coffee in Northern Tanzania Using SAFERNAC. International Journal of Plant \& Soil Science, 3(9), 1096-1111. https://doi.org/10.9734/IJPSS/2014/8361 
Maro, G., Janssen, B., Msanya, B., \& Mrema, J. (2014). Economic Optimization of Nutrient Application to Coffee in Northern Tanzania Using SAFERNAC. International Journal of Plant \& Soil Science, 3(9), 1096-1111. https://doi.org/10.9734/IJPSS/2014/8361

MDC. (2010). Investment Plan for Sunflower Production in Mbozi District. 29.

Mhando, D. G., \& Mdoe, S. M. (2018). Why Do Smallholder Famers In Four Tanzanian Districts Continue With Coffee Production Despite Fluctuating Prices? Journal of Agriculture \& Life Sciences, 5(2), 1-10. https://doi.org/10.30845/jals.v5n2p3

Mhando, D. G., \& Ntengua Mdoe. (2017). Mid-term Evaluation Report of the Tanzania Coffee Industry Development Strategy 2011-2021 (pp. 1-29). BACAS. Sokoine University of Agriculture.

Mignouna, D. B. (2011). Adoption and Impact of Improved Agricultural Technologies in Developing Countries: The Case of Imazapyr-Resistant Maize in Western Kenya [A Thesis Submitted in Fulfilment of the Requirements for The Degree of Doctor of Philosophy]. Sokoine University of Agriculture.

Mmbando E., F., \& Baiyegunhi J.S, L. (2016). Socio-economic and Institutional Factors Influencing Adoption of Improved Maize Varieties in Hai District, Tanzania. Journal of Human Ecology, 53(1), 49-56.

Mohammed, M. K. (2018). Analysis of Adoption of Improved Coffee Technologies in Major Coffee Growing Areas of Southern Ethiopia. Innovative Systems Design and Engineering, 9(5), 1-9.

Mondal, M. H. (2011). Causes Of Yield Gaps And Strategies For Minimizing The Gaps In Different Crops Of Bangladesh. Bangladesh Journal of Agricultural Research, 36(3), 469-476. https://doi.org/10.3329/bjar.v36i3.9274

Mtenga, D. J. (2016). Diversity, Combining Ability and Coffee Berry Disease

(Colletotrichum Kahawae) Resistance Among Ethiopian and Tanzanian Arabica Coffee Genotypes [Thesis submitted for the degree of Doctor of Philosophy].

Sokoine University of Agriculture.

Muellbauer, J. (1974). Household Production Theory, Quality, and the "Hedonic Technique.” American Economic Association, 64(6), 19.

Mwakalobo, A. (2005). Assessing Agricultural Productivity among Smallholder Coffee Farmers in Tanzania: Evidence from Rungwe District. JCEE, 2(1), 11.

Mwakatwila, A. (2016). Adoption of Improved Maize Varieties in Northern and Eastern Zones of Tanzania [Dissertation Submitted in Partial Fulfilment of the 
Requirements for The Degree of Master of Science]. Sokoine University of Agriculture.

Nyanga, P. H. (2012). Factors Influencing Adoption and Area under Conservation Agriculture: A Mixed Methods Approach. Sustain. Agric. Res, 1.

Nzeyimana, I. (2018). Optimizing Arabica coffee production systems in Rwanda: A multiple-scale analysis. Wageningen, 143. https://doi.org/10.18174/448555

Omair, A. (2015). Selecting the appropriate study design for your research: Descriptive study designs. Journal of Health Specialties, 3(3), 153. https://doi.org/10.4103/1658-600X.159892

Robinson, R. J. (1961). Fundamentals of acid-base regulation. Fundamentals of acidbase regulation.

Rogers, E. M. (1962). Diffusion of Innovations (Third Edition). Free Press of Glencoe.

Rogers, E. M. (1995). The Diffusion of Innovations (4th ed.). The Free Press; A Division of Simon \& Schuster Inc.

Sadras, V. (2015). Yield gap analysis of field crops: Methods and case studies.

Sänger, C. (2018). United Nations Conference on Trade and Development: State of the global coffee market. 10th Multi-Year Expert Meeting on Commodities and Development, 36.

Schulthess, U., Timsina, J., Herrera, J. M., \& McDonald, A. (2013). Mapping field-scale yield gaps for maize: An example from Bangladesh. Field Crops Research, 143, 151-156. https://doi.org/10.1016/j.fcr.2012.11.004

Seleman, S. A. (2017). Assessment of Gender Inequality in Participation in Coffee Production and Marketing: A Case of Kigoma District Council [Dissertation Submitted in Partial Fulfilment of the Requirements for The Degree of Master of Science]. Sokoine University of Agriculture.

Setia, M. (2016). Methodology series module 3: Cross-sectional studies. Indian Journal of Dermatology, 61(3), 261. https://doi.org/10.4103/0019-5154.182410

TaCRI. (2011). “Kanuni za Kilimo bora cha Kahawa: Kahawa ya Arabika”. A TaCRI Publication (Coffee Productivity \& Quality Improvement Programme) (1st Edition). Tanzania Coffee Research Institute.

TaCRI. (2017). Strategic Action Plan IV. 2017/2018-22/2023 For Tanzania Coffee Research Institute: Prepared by Diligent Consulting LTD with financial support from EDF, DSM (Issue April 2017).

Tamene, L., Mponela, P., Ndengu, G., \& Kihara, J. (2016). Assessment of maize yield gap and major determinant factors between smallholder farmers in the Dedza 
district of Malawi. Nutrient Cycling in Agroecosystems, 105(3), 291-308. https://doi.org/10.1007/s10705-015-9692-7

TCB. (2012a). Tanzania coffee industry development strategy 2011/2021. Tanzania Coffee Board.

TCB. (2012b). Tanzania coffee industry development strategy 2011/2021.

TCB. (2018). Bodi ya Kahawa Tanzania: Sekta Mpya ya Kahawa Tanzania; Mkutano Mkuu wa Tisa wa Wadau wa Kahawa.

Teferi, A., Philip, D., \& Jaleta, M. (2015). Factors that affect the adoption of improved maize varieties by smallholder farmers in Central Oromia, Ethiopia. 10.

Tittonell, P., \& Giller, K. E. (2013). When yield gaps are poverty traps: The paradigm of ecological intensification in African smallholder agriculture. Field Crops Research, 143, 76-90. https://doi.org/10.1016/j.fcr.2012.10.007

Udensi, U. E., Tarawali, G., Favour, E. U., Asumugha, G., Ezedinma, C., Okoye, B. C., Okarter, C., Ilona, P., Okechukwu, R., \& Dixon, A. (2011). Adoption of selected improved cassava varieties among smallholder farmers in South-Eastern Nigeria. 8.

URT. (2013). 2012 Population and Housing Census (p. 264) [Census General Report]. National Bureau of Statistics Ministry of Finance Dar es Salaam and Office of Chief Government Statistician President's Office, Finance, Economy and Development Planning Zanzibar.

van Bussel, L. G. J., Grassini, P., Van Wart, J., Wolf, J., Claessens, L., Yang, H., Boogaard, H., de Groot, H., Saito, K., Cassman, K. G., \& van Ittersum, M. K. (2015). From field to atlas: Upscaling of location-specific yield gap estimates. Field Crops Research, 177, 98-108. https://doi.org/10.1016/j.fcr.2015.03.005 van Ittersum, M. K., Cassman, K. G., Grassini, P., Wolf, J., Tittonell, P., \& Hochman, Z. (2013). Yield gap analysis with local to global relevance-A review. Field Crops Research, 143, 4-17. https://doi.org/10.1016/j.fcr.2012.09.009

Wale, E., Holm-Müller, K., Mburu, J., \& Zeller, M. (2005). Economic analysis of farmers' preferences for coffee variety attributes: Lessons for on-farm conservation and variety adoption in Ethiopia. Quarterly Journal of International Agriculture, 44(2), 20.

Wu, L. (2005). Does size matter in Chinese farm household production. Agricultural Economics Society Annual Conference, University of Nottingham, Nottingham, UK. 
Yusi, S. (2016). The analysis of production function and farm marketing efficiency of pineapple (Ananas comosus L Merr) in South Sumatera Province, Indonesia. African Journal of Agricultural Research, 11(23), 1990-1998. https://doi.org/10.5897/AJAR2016.10863 
Figures

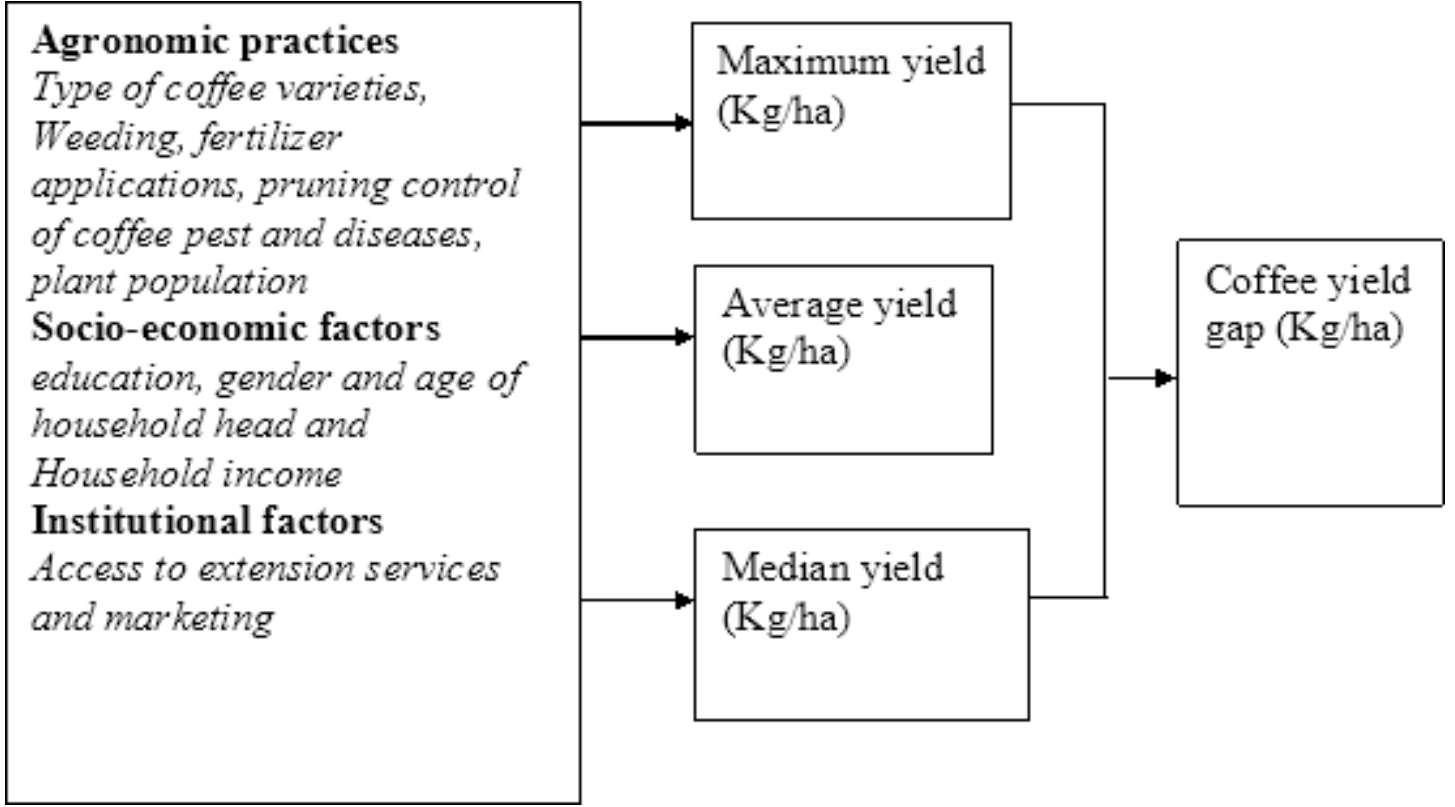

Figure 1

Conceptual framework developed by author

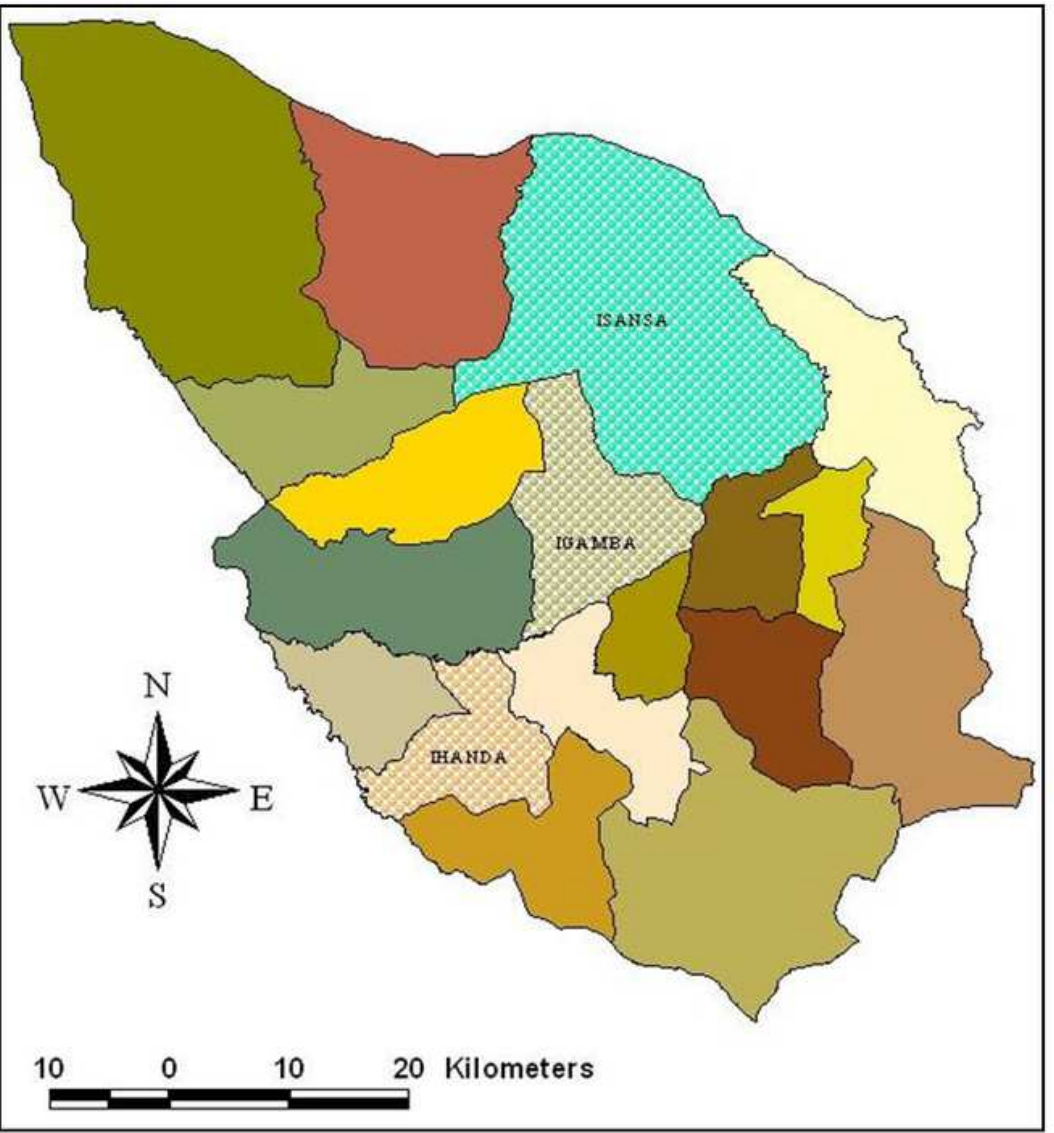

a

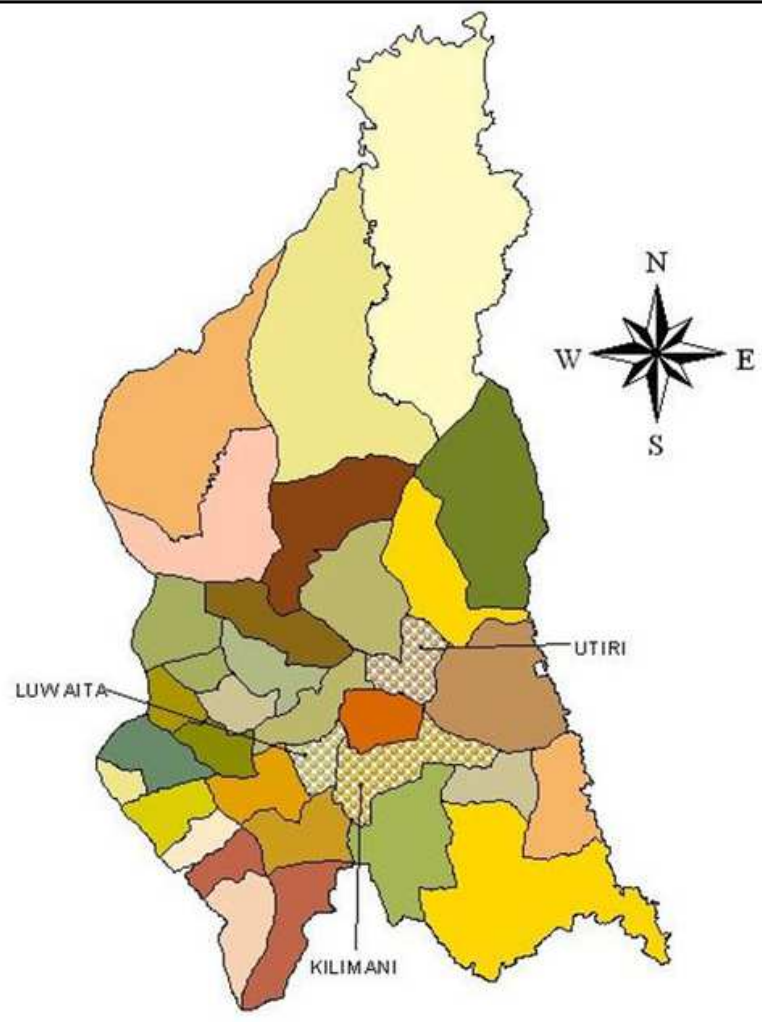

$\begin{array}{llll}10 & 0 & 10 & 20 \\ & \text { Kilometers }\end{array}$ 
a. Map of Mbozi District, study wards in dotted texture; b. Map of Mbinga district, study wards in dotted texture 